\title{
Neoliberal Development and Struggle Against It: The Importance of Social Class, Mystification and Feasibility
}

\author{
Alpesh Maisuria ${ }^{*}$ ) \\ ${ }^{*}$ ) University of East London - London - UK
}

\begin{abstract}
In this article I introduce and develop neoliberalism through a discussion of Marxism and the way that classed mystification and feasibility are crucial concepts for understanding the maintenance of neoliberalism, and revolutionary possibilities.

The starting point for this article is an essential explication of the Marxism, which is argued as the most efficacious theoretical framework for understanding the current historical conjuncture. Then, I provide an understanding of the development of capitalism into its current neoliberal form and its core features. Doing this work is important because while scholars regularly refer to capitalism/neoliberalism, they rarely explicate its fundamentals. Having this specification will provide a referent for the analysis for the discussion in the article. This incorporates the question: what mechanisms generate the tendency for most people to acquiesce (or even assent) to neoliberalism, despite the inequality and inequality it creates? To address this, I suggest the critical importance of mystification.

While exposing neoliberalism is important I argue that analysis and critique alone is not sufficient. I draw the article to a close by presenting a discussion about the importance of the feasibility of an alternative to neoliberalism to be promoted by critical educators and Marxists. The possibility of resistance and revolution emerges through constructing, what Gramsci called, a new conception of the world.
\end{abstract}

Keywords: Neoliberalism, Marxism, Marx, Social Class, Revolution.

\section{Desarrollo neoliberal y lucha contra él: la importancia de la clase social, la mistificación y la viabilidad}

\section{RESUMEN}

En este artículo, presento y desarrollo el neoliberalismo a través de una discusión sobre el marxismo y la forma en que la mistificación y la factibilidad clasificadas son conceptos cruciales para comprender el mantenimiento del neoliberalismo y también las posibilidades revolucionarias.

El punto de partida de este artículo es una explicación esencial del marxismo, que se argumenta como el marco teórico más eficaz para comprender la coyuntura histórica actual. A continuación, proporciono una comprensión del desarrollo del capitalismo en su forma neoliberal actual y sus características principales. Hacer este trabajo es importante porque a menudo, cuando los académicos se refieren al capitalismo / neoliberalismo, rara vez explican sus fundamentos. Tener esta especificación proporcionará una referencia para el análisis de la discusión en el artículo. Esto incorpora la pregunta: ¿qué mecanismos generan la tendencia de la mayoría de las personas a aceptar el neoliberalismo a pesar de la desigualdad que crea? Para abordar esto, sugiero dotar de mayor importancia la crítica de la mistificación. A este respecto considero que si bien la exposición al neoliberalismo es importante, sostengo que el análisis y la crítica por sí solos no son suficientes. Concluyo el artículo presentando una discusión sobre la importancia de la viabilidad de una alternativa al neoliberalismo para ser promovida por educadores críticos y marxistas. La posibilidad de resistencia y revolución emerge a través de la construcción, lo que Gramsci llamó, una nueva concepción del mundo.

Palabras Clave: Neoliberalismo, Marxismo, Marx, Clase Social, Revolución.

\section{What is Marxism}

Ideas of class struggle along with class formation and class consciousness are at the core of Marx's (1818-1883) works and scholars who have subsequently subscribed to the effectiveness of Marxism to critique the modern world and particularly inequality. To comprehend the central importance of the articula- tion between these ideas, a basic understanding Marxism is useful to contextualise class struggle and resistance to neoliberalism.

Some people understand Marxism as being: i) exclusively about social class, for instance that other identities do not matter, and/or ii) that social class was the point of departure for Marx in his critical treatment of the development of capitalism. Marx actually began with a primacy on the mode of production, not so- 
cial class. Put simply, mode of production is the focus on which group of people in society produces commodities; and importantly for social justice, what happens to the wealth that is generated through exchanging these commodities. It important to say that these relations of production are not optional, nobody can decide to step outside of the neoliberalism as they may wish, it has almost encapsulated the entire world through its ubiquitous domineering economic and socio-cultural system. This is about the globalisation of the capitalist money system, this means that it is almost impossible to not use a capitalist bank to be paid a salary, or succumb to a mortgage, or work for an organisation that is linked to capitalist development; put simply capitalism dominates and it largely entraps, thus to overcome it necessitates an understanding of it. Marx had predicted this and the emergence of globalisation of capitalism over 150 years ago:

In the social production of their life, men enter into definite relations that are indispensable and independent of their will, relations of production which correspond to a definite stage of development of their material productive forces. The sum total of these relations of production constitutes the economic structure of society, the real foundation, on which rises a legal and political superstructure, and to which correspond definite forms of social consciousness (Marx, 1859 [my emphasis]).

The point that Marx was making was that the dominant condition of everyday life is created by the mode of production, this shapes the way that people think and act, in other words there is nothing about capitalism that is part of human nature. Human selfishness and greed in a world of plenty is learnt, not biological. The capitalist system stridently promotes a fetish of commodities, this is development of an insatiable appetite of consumerism - wanting bigger, shinier stuff and luxury, at any expense.

Furthermore, in the current neoliberal phase of global capitalism (discussed below and also see Maisuria, 2014 for an explanation of this), commodities can be taken to mean more than just goods such as products, it can also include services too, such as education and more recently knowledge itself (Marmol et al, 2015). An example of the latter is McGraw-Hill, which will be discussed later.

\section{Focus on production}

In Marx's Capital (originally published as Das Kapital) he explained that society organised by capitalist mode of production has the basic feature of two antagonist classes: i) the ruling (bourgeois) class, this is the class that owns the means of production; ii) and the labouring (proletariat) class, those who use their capacity to work to produce commodities for the ruling class (Rikowski, 2001). Crucially the work that is done by the labouring class produces commodities for the ruling class who then exchange and accumulate wealth through making a profit. Profit is the net revenue from a sale, Marx put it this way:

Surplus value - profit - is the value produced by worker expenditure of labour-power on the means of production. It is the value determined, ultimately by capitalist class practices in their totality, to be above and beyond ("surplus") the value that the owner must pay in wages to the labourer to ensure she is able to reproduce her labour-power (Marx, 1867).

Marx foresaw that the nature of capitalist thinking, which was that exploitation was inherent as part of relationships, hence he said it was the goal of the ruling class "To extract the greatest possible amount of surplus-value, and consequently to exploit labour-power to the greatest possible extent," this Marx argues, is "the directing motive, the end and aim of capitalist production" (Marx, 1867).

Marx foresaw the development of a society under capitalism in which the ruling class would gradually become enormously wealthy through the work of the labouring class. In this historical evolution, the profits of those who own the means of production (see any rich list for names - every year this will include Warren Buffett, Carlos Slim and Bill Gates) will exponentially become greater, while workers' wages will remain stable, decrease or only marginally increase - this is the idea of exploitation. The increasingly exploitative relationship between the two classes was described by Marx in the following terms: "The history of all hitherto existing society is the history of class struggles" (Marx and Engels, 1848). It is important to note that this exploitation is irrespective of identity and personal characteristic of the workers, put another way, capitalism does not care for ethno-racial, sex/gender, and cultural preferences of the individual. In this context, production is at the forefront of Marx's thinking with social class being articulated within the nexus of labour exploitation, commodity exchange and profit.

\section{A two-class model in contemporary society}

Critics of Marxism point out that in modern society there are not only two classes, and that most people probably self-identify as middle class thus echoing former British Prime Minister Tony Blair who suggested that "We're all middle class now". While this statement may be true about self-identification, Marxists would point out that the idea of a working class in neoliberal capitalism is broad and crucially includes a middle class. In this conception of two classes, the so-classed middle class are simply those in the working class who have more material/financial resources and wellbeing - but to attain this status, the middle class still need to work, hence they are part of the labouring class, albeit with the possibility to buy more, and more expensive commodities (perhaps through debt). In this way most academics and even bankers can be considered to be workers because they need to work in order to sustain themselves (and pay debt) in the capitalism system where the majority of people sell their labour to the ruling class. It is this context that the recent Occupy Movement's slogan - the 1\% Vs $99 \%$ - becomes a description of reality as it is lived.

In fact, $1 \%$ is not quite accurate, ownership of the means of production, private property and wealth is concentrated in more like the $0.01 \%$. To put into context, the astronomical differentiation, the gap between the $1 \%$ and the $0.01 \%$ is greater than the gap between the $1 \%$ and the $99 \%$, in other words wealth increments are exponential. Inequality is measured in various metrics, including wealth distribution and poverty levels, but rarely do they account for concentration in the ownership of production, which is a far more accurate way to understand the generative mechanism of inequality and unfairness.

When Marx was developing his theory of capital, exchange and markets - he was writing in a time of new individual landowners (emerging post-feudalism). In current neoliberal times, markets have been monopolised by global transnational corporations. This means that the two-class model is reconfigured: i) From Individual landowning class (capitalist) to transnational companies ii) From manual labouring class, to a working class that including skilled and service sector employees. While companies are in competition with each other, they are actually linked in a web of interconnected companies. Three systems the- 
orists at the Swiss Federal Institute of Technology in Zurich have analysed database listing 37 million share ownerships linking them (Vitali, Glattfelder, Battiston, 2011). This mapping exercise is the first of its kind and there is need for more research given that they found that just 147 transnational companies own all commodity production. The 2008 economic crises that triggered a global capitalist recession makes more sense when markets are conceived of as a domino effect. Incredibly according to Forbes, these 147 transnational companies are themselves controlled by "economic super-entity" core of comprising of just 4 that own the entire system of commodity production (Forbes, 2011). It tells its own story of mystification (discussed below) that most people would never have heard of: Northwestern Mutual, which owns Russell Investments, the index arm of which runs the benchmark Russell 1,000 and Russell 3,000; CME Group, which owns 90\% of Dow Jones Indexes; Barclay's which took over Lehman Brothers and its Lehman Aggregate Bond Index, the dominant world bond fund index, McGraw-Hill, which owns Standard \& Poors, who deal with financial market indicators and investment. Above discussed McGraw-Hill's educational arm who now not only publish scholarship they are now a Learning Sciences Company; in other words, they are now knowledge producers meaning that knowledge is a commodity, and it is specifically a certain kind of knowledge, which undoubtedly will not effectively critique capitalism itself.

With this understanding of the basics of Marxism and the emphasis on production, the idea and attention to class struggle, articulated with class consciousness, is fully understandable and profound. In neoliberal global capitalism it is clear that a tiny minority are the winners of opportunity, wealth and a good-life, and many more are exploited and alienated despite claims of, and a prevailing belief in, meritocracy and social mobility. It is important to recognise that these claims of the existence of meritocracy and mobility are important to pacify resistance and generate acquiescence to a grossly unfair and unequal system, and they are mechanisms in which people cannot even conceive of a feasible alternative system to be possible. Within this dominant hegemony the need for class consciousness to be continuously developed is crucial, thus to mobilise class action struggling for a different kind of world, beyond neoliberalism, where the many can flourish. But there remains the ambiguity about what neoliberalism is.

\section{Neoliberalism}

Professor Mike Cole and I have summarised neoliberalism (see Maisuria and Cole, 2017). Taking the cue from Milton Friedman and Friedrich Hayek that follows an Adam Smith economic modelling, economists in the USA known as the Chicago Boys developed a fundamentalist free market ideology that was first experimented with on 11 September 1973 in Chile. A US-backed military coup resulted in the death of democratically elected socialist Salvador Allende, which was a suspected murder. His replacement was the military General Augusto Pinochet, who would impose a brutal dictatorship in the interests of capital. Within a five-year period (1970-1975), the Chilean economy shifted from State-controlled major industries to a system that centred on market forces, self-interest, and laissez faire regulatory governance (Maisuria, 2014). As Jonathan Barton explains, the military junta was crucial in this process, with harsh repression and the banning of trade unions, making labour power very flexible with respect to wages and discipline (Barton, 1999, p. 66, cited in Lawton, 2012). As such, Chile became a haven for multi/trans-national companies eager to exploit the country for capital accumulation. Subsequently, wealth disparities between rich and poor increased dramatically. As Thomas G. Clark (2012) explains, the neoliberal experiment in Chile began the future imposition of right-wing military dictatorships, and through financial support to impose neoliberal reforms became unofficial US foreign policy.

The neoliberal ideology was given ballast to globalise when Margaret Thatcher in the UK who was keen Adam Smith admirer was elected, tellingly she was a friend and proponent of Pinochet who in 1999 thanked him for bringing 'democracy to Chile' (BBC, 1999). Neoliberalism would become orthodoxy when Ronald Reagan was elected a few years after in the US. Both Thatcher and Reagan set about stridently introducing neoliberal reforms, such as the complete withdrawal of capital controls instigated by UK Tory Chancellor Geoffrey Howe, and the deregulation of the US financial markets - euphemistically termed the Big Bang of Regulation. By 1989, the ideology of neoliberalism was enshrined as the economic orthodoxy of the world. The global financial Washington-based institutions, such as the International Monetary Fund (IMF), the World Bank, and also the US Department of the Treasury, signed up to a 10-point economic plan. This plan was about trade liberalization, privatization, financial sector deregulation, and tax cuts for the wealthiest (Clark, 2012). As Clark concludes, 'this agreement between non-elected and shady organisations is misleadingly referred to as "The Washington Consensus" (Clark, 2012). The signing of the General Agreement on Trade in Services (GATS) in 1994 gave global neoliberalism a major boost by removing restrictions and internal government regulations in the area of service delivery that were considered 'barriers to trade' (GATS, 1994). The word neoliberal itself, however, did not enter the common vocabulary until November 1999 with the symbolic protest against the World Trade Organization (WTO) in Seattle. This meant that Thatcher and Reagan were not known by the electorate as neoliberals, nor were they associated with Chile, had this been the case history may have been different and it remains the case that Thatcher and Reagan are largely disassociated with Chile.

Because neoliberalism has had an organic rather than prescripted evolution across the globe, it is important to identify some defining features. Adapting Martinez and Garcia (2000), there are three inter-related core mechanisms that necessitate the neoliberalisation processes.

Firstly, the predominance of the rule of the market in policy making. This incurs liberating private enterprise from most bonds imposed by the government and other State institutions. Greater openness to international trade and investment, as in the North American Free Trade Agreement (NAFTA). Essential reducing of wages and facilitating greater exploitative industrial relation for capital by disallowing unionisation or significantly curtailing their power. Deregulating is important for marketisation, for example few price controls to enable freedom of movement for capital, goods, and services. The claim is that 'an unregulated market is the best way to increase economic growth, which will ultimately benefit everyone. This is akin to Reagan's supply-side and "trickle-down" economics - but wealth trickling downwards is minimal, compared with the wealth being syphoned up, especially when capital and profits are wanted by the ruling class. An example is austerity politics, which is about a retrenchment of public services and welfare while maintain the class system.

Secondly, marketisation necessitates commodification for privatisation. This entails cutting public expenditure on public services and welfare. Education and health care provision are first to be euphemistically 'reformed', 'streamlined', and made 
more efficient. This means that potentially financially profitable public services and common goods are commodified, to be sold to the private sector. In the world of business, this would be called asset stripping and recent examples include, State banks, and key industries: railroads, toll highways, electricity, schools, hospitals and even water supply. Often this is through quasi-privatisation in the form public-private contracts, such as those in Sweden with Free Schools and England with the Academies Programme. The effect has been poorer and/or inaccessible services because of the introduction of fees and also concentrating wealth and power even more in private sector. The irony is that this creates monopolies, such as the energy companies in England, thus reducing the competition and choice that markets were designed to mobilise. Neoliberals claim that commodification introduces choice, and creates power for the consumer, for instance leveraging parental power/choice in education, but the reality is that those with financial capital are the winner because they can afford a wider selection of choices. The result is social class reproduction.

Thirdly, there is a socio-cultural narrative that is needed to be created by neoliberals. This narrative is to promote self-interest, individualisation, and focus individuals on personal investment. To sustain neoliberalism, the masses need to buy into it. Neoliberalism nefariously focuses on winning the masses hearts and minds. The relative (though not hermetically sealed) success of dichotomies such as (hard) workers vs (lazy) shirkers/scroungers since 1979 after Thatcher's election continues. This narrative has resulted in a devaluing of the concepts of building society, unity, compassion, solidarity. The replacement is individual-responsibility, entrepreneurialism, dog-eat-dog, cut-throat competition (see later for a discussion on social mobility and meritocracy) at the level of individual people (and also companies). In this the worker becomes alienated and the agent of their own oppression.

Importantly, in the current neoliberal phase of global capitalism (see Maisuria, 2014 for an explanation of this), commodities (as defined above) can be taken to mean more than just goods such as products, it can also include services too, such as education and more recently knowledge itself (Marmol et al, 2015). An example of the latter is McGraw-Hill, who until recently was one of largest companies in the world trading in publishing, more recently have tapped into selling knowledge itself, which they call 'learning science'. McGraw-Hill as a learning sciences company is an edu-business that makes a series of claims on its website, here are four examples. First, that it is a Learning Sciences Company - to "help people learn", but it does not specify what is learnt? Second, it claims to "bring that content or deliver that content", but what is the content? Third, they claim "we're focussed on outcomes", but whose outcomes are these and for what? fourth, McGraw-Hill "measure those results", but measure results against what and to achieve what? In the capitalist mode of production these questions are important because the influence of capitalist rationality is ubiquitous, and it extends its reach in to public services and social entitlements, transforming the commons into commodities. Ultimately, the ruling class are the beneficiaries and their stake in wealth and power increases, but this consequence of the dominant mode of production is mystified - meaning made ambiguous.

\section{Mystification of capitalist mode of production}

The British comedian and activist, Russell Brand with his brilliant firebrand use of satirical comedy in his film The Emperor's New Clothes, exposes astronomical level of income inequali- ty between workers and the capitalist class. For instance, in the film he shows that, such is the level of income inequality in 2015, it would take 300 years for an average cleaner, cleaning the office of a capitalist, to earn the same as that capitalist. These are powerful demystifying facts to disseminate explicating inequality and exploitation invoking questions about especially ethics, morals, and civility itself in the epoch of neoliberal capitalism. However, and crucially, what Brand does not do is address the key question - with so much inequality how does the status quo remain and continue to gain acquiesce (meaning consent that is also critical) and even assent (enthusiastic consent) from the masses of the exploited class? This neat trick is what sustains and maintains the neoliberal capitalist mode of production.

To address this question, the concept of mystification becomes powerfully useful. It can be used to descriptively understand a condition in which there is prevailing perceptions that masks and obscures a deep reality of the capitalist mode of production that creates inequality. Put simply, the labouring class do not, are encouraged not to, connect the neoliberal global capitalism with inequality and unfairness. This conditioning happens in several overlapping ways and forms.

People are told it is too much of a difficult subject to discuss political-economy and ideology and leave it to the experts - who are themselves the beneficiaries. Or people are told it is not important, politicians often assert that their policies are about what works and what's right not ideological dogmas. As the director Adam Curtis shows in his storming film Bitter Lake, the ruling class across neoliberal nations have adopted the same strategy to govern with the aim to confuse the masses - mystification. This allows them to get on with deepening neoliberalism through expanded markets and privatisation, despite these being the mechanisms that gave the catalyst for austerity, inequality and inequity that the ruling class claim to oppose.

Mystification of capitalism and neoliberalism is not the work of serendipity, it is a purposeful strategy by the capitalist class to promote, manufacture and disseminate a particular culture and popular common sense, in education and everywhere. In essence, this is to emerge in a dominant belief that inequality is result of some people being deserving rich, which is the basis of meritocracy (strivers) and equally there is a deserving poor (skivers) - who haven't tried hard enough, been: ambitious, aspiring and motivated. This is about promoting a focus that diverts attention away from the capitalist system that works for the interests of the few at the expense of the many, and to the encouraging a culture of demonization that advocates individualism and self-interest. The popular representation of the super-rich people (earlier I noted Warren Buffett, Carlos Slim and Bill Gates) is that they deserve their wealth and to critique is traduced as merely a politics of envy or even worse a lack of ambition. Marxists would counter that, while these individuals are products of the system that they have manipulated to have their riches, for the sake of progress and civilisation we must question how neoliberalism can be fair and moral when these people have so much while there are so many in the world who can scarcely afford food and water (Choonara and Robinson, 2008).

The mystification discussed above partly emerges as a condition that circumscribes class consciousness because neoliberals do not want, and indeed see it as a threat, to discuss and educate about neoliberalism (see discussion above about Thatcherism). Furthermore because of the absence of education systems that fails to include critique of neoliberalism, mystification is also serviced by the occurrence of miracles. These miracles are instances of when individuals 'make it' against the odds of success, and these are promoted as being suggestive of their being an absence 
of a glass ceiling and sticky floor for the worse-off in society. There is a concerted attempt to create a mass belief in the existence of meritocracy and social mobility. The success of this narrative generates justification of staggering inequality by absenting neoliberalism (see any annual Oxfam Inequality report), i.e. those people who are poor are deemed to have not tried hard enough and taken opportunities to succeed and therefore deserve their lot - neoliberalism has nothing to do with it. With the consciousness of a deserving poor, also comes the idea of deserving class of people who have worked hard to become prosperous, privileged, and powerful. This consciousness is cultivated by the ruling elite on a regular basis, and the media central plays a part in normalising it. A good example is a recent article in the newspaper London Evening Standard with the headline: Migrant's son swaps the East End for Eton after winning scholarship. The central argument in the article was that anybody could make-it with hard work, and this working-class boy, the son of immigrants, can join the likes of the future King of England at Britain's most elite school. A notable segment of the article discussed the boy's view of his father and his struggle to make work pay: "My dad has a lot of injuries, shattered knee and slipped disc, but has instilled morals and ethics that you have to work. ... . He is always at work trying to make life better for his family. He is my hero" (Barnes, 2017). Crucially, the article shifts the emphasis on individual endeavour and away from the capitalist system that is unequal and unfair and reproduces this injustice through the very fact that a private school that charges $£ 37 \mathrm{k}$ (Euro $42 \mathrm{k}$ ) tuition fees annually exists at all. Moreover, implicitly, the article dismisses the fact that there are potentially hundreds of pupils in London's poor East End who will never have the opportunity to study at Eton. The one boy who did progress was an anomaly, and his fortune was largely an accident of time and moment. The common sense being promoted, to solidify the dominant hegemony, is that if one boy can make it to Eton then everybody can (for an elaboration see Maisuria, 2017).

Working against mystification and promoting a belief in the feasibility of alternatives to the neoliberal class-based status quo is probably the greatest task for critical educators and activists for social justice.

In Western and developed countries, the struggle is hard because neoliberal capitalism is deeply established in the ideological, political, social and cultural realms that are enmeshed in creating the conditions in which a mass common sense is manufactured, for example about selective education being drivers of equality. This common sense that has prevailed, since the fall of the Berlin Wall, emerges through some has identifiable mechanisms. These are oscillating in degrees of intra-dependency between:

i) Neoliberalism best serves the economy through talented individuals being rewarded:

a. Self-interest is key for us all to individually prosper.

b. The investment in the concept of society, rather than self, promotes social loafing and laziness. Selfishness is good because it incentivises and motivates.

ii) There is no alternative (TINA) to the status quo.

iii) The alternatives to neoliberal capitalism that may/do exist are not feasible because:

a. They are less desirable because they promote reliance on welfare - those who scrounge from the State or rely on others to be productive,

b. on balance, the status quo is as good as it gets. The problems of inequality are outweighed by the good stuff (i.e. the availability of commodities - i.e. Cuba), c. In the end, the communist/socialist alternative is not feasible because it is idealist and utopian, not practically realistic.

iv) Inequality is natural. It has always existed in human relations, and always will. It is nature.

v) We are genetically wired to be competitive and neoliberalism facilitates this most inner urge. Self-interest promoted in political economy and socio-culture (i.e. education policy that focuses on personal investment and return in the labour market) aligns with our nature.

vi) Neoliberalism advances civilisation through advancement in productive technologies.

These messages are imprinted ubiquitously, and they are the mechanisms that generate the appearance of the narrative that a) nothing needs to be done b) nothing can be done for serious change. This latter point is effectively symbolized in the popular British cultural slogan: keep calm and carry on with suffixes such as shopping, drinking tea, and so forth. While these narratives and slogans may seem benign, they represent a deep mechanism of mystification which generates a tendency for the maintenance of dominant class ideology in every auspice of lived reality that is almost inescapable. The point here is that the dominant hegemonic ideology cannot exist without the apparatus that support it in lived reality. For example, neoliberalism cannot be maintained by the ruling class without the supporting organs, which includes schools and popular culture that seek to establish the lived conditions for its consent. Notably, I have used the word "appearance" with purpose to denote its superficiality and precarity at negating the alternatives in consciousness and practices. The strategy for struggle is for educating about class relations and neoliberalism Along with the belief in social mobility and meritocracy, people have been conditioned to get-on with life with the message be a striver rather than a moaning skiver. In addition, very few people would want to risk themselves against the very powerful State apparatus. The eliding of these forces means that there is relative (in)stability. However even in this state of general and mass acquiescence, spaces always exist for struggle because appearances are difficult to maintain with gross inequality and inequity.

\section{Feasibility of Alternatives}

The Italian communist Antonio Gramsci viewed that it was necessary for the masses to have a new conception of the world, thus meaning that people must be convinced to believe that history is open to new ways of being, and this could be facilitated by revolution (Gramsci, 1971, p.465; Forgacs, 2000, p.429). In recent times it seems that a consciousness is emerging amongst the labouring classes that, specifically, democracy is used as a mechanism of appeasement as well rendering alternatives as unfeasible. For many years, the ruling class hegemony has been created by an appearance of equity and social mobility and meritocracy exists; but this appearance is being unveiled and demystified. The prevailing mass consciousness has been that democracy is what differentiates the free (neoliberal) world from the (non-neoliberal) unfree world but this appearance is wearing thin. The ruling classes have continually reproduced their hegemony via (i) mass apathy to politics and also by (ii) people actually participating in parliamentary politics voting for a mainstream Party, the function of both practices results in maintaining the status quo of neoliberal capitalism. The emerging problem for the capitalist ruling class is that the previously apathetic masses are seemingly more aware of their inaction, and apathy is be- 
ing channelled into more class-conscious practices. The massive support of comedian turned political activist Russell Brand, Podemos and other examples such as the Occupy and Uncut movements are demonstrative of the embryo of a people's class consciousness emerging as part of hegemonic struggle.

Parliamentary democracy is now under scrutiny like it has never been before. The cultural apathy and acquiescence that maintained and reproduced class relations is being questioned against claims of political representation through voting. The mentality that Brand describes as "Stick your X into this box and congratulate yourself on being free" (Brand, 2014, p.78) is no longer cultivating consent as it has historically. However, things may be about to change with the popularity of the likes of Corbyn, Sanders, Obrado who suggest feasible alternatives to marketisation and privatisation of education and other public provision. They are providing leadership for a feasible alternative for the labouring class to consider. This is a radical departure from just a few year ago, and Brand effectively points out the way in which oppositional consciousness was situated as culturally deviant and/or dealt with, by ad hominem:

When I was poor and complained about inequality they said I was bitter; now I'm rich and I complain about inequality they say I'm a hypocrite. I'm beginning to think they don't want me to talk about inequality (Brand, 2014, p.113).

Brand is being used as an illustration here because he represents something interesting from a Marxist perspective. As a global celebrity who came from a troubled and humble background, he represents the ultimate Hollywood dream. His story effectively shows that in neoliberalism people can make it against the odds, the message is mystified as social mobility and meritocracy, rather than miracles. But what is interesting is why Brand would turn his back on capitalizing further on the trappings of the good life and devote his time, money and energy on acting against the very system that brought him financial prosperity. This life history opens-up the valuable idea that beyond basic needs financial reward is: vacuous, superficial, unfulfilling and unsatisfactory. Put simply, there is more to life than the language of money and consumption. More importantly, his life represents the emergence of a revolutionary consciousness that exists within neoliberalism itself (Marx and Engels, 1848; Mayo, 2015). In the case of Brand, he had taken neoliberalism to its limits, and it was during this neoliberal journey itself that he became conscious of classed exploitation and alienation. The point is that the lived world in neoliberal times incorporates social transformation within itself, revolutionary ideas are generated within this materialism not outside of lived reality. Class consciousness and desires of personal and political change are not separate from the world that is experienced. Brand's journey is demonstrative of the Gramscian idea that "all men [sic] are intellectuals" (1971, p.9). He is somebody who had lived the common sense of neoliberalism and came through this with good sense.

For criticism to be effective in contextualising the need for change, it needs to be accompanied by visions of utopia as feasible. Utopia is deployed here not to mean a fantastically perfect paradise but rather an alternative where wealth and power is massively redistributed, and social justice, equality, equity, and political representation take priority over markets, commodities and privatisation. Many neoliberals, especially of the free market Milton Friedman and Friedrich Hayek type (see the Adam Smith Institute), argue that there are no feasible alternatives any longer (as discussed earlier). However, examples outside of Stalinist regimes show that, where stridently implemented, democratic socialism has benefitted the masses far more than capitalism has. Earlier the issue of participation in parliamentary democracy was discussed and, in this context, it has been shown that democracy works better in socialism than in capitalism given that in presidential elections in socialist countries regularly $80 \%$ of eligible voters actually vote, giving a genuine mandate to the victor, as was the case with the late President Hugo Chavez of Venezuela. The case of Cuba arises continually as a point that critics use to dismiss claims of a feasible radical-Left alternative and democracy existing simultaneously. The term dictatorship is often casually deployed by neoliberal-advocate/apologists in these discussions about Cuba. However, the case of Cuba shows that democracy can be more representative and in the interest of people when democracy is about socialism and solidarity.

In Cuba, bottom-up political representation is alive and thriving, it is designed to be integral to the governing system. The principle behind Committee for the Deference of the Revolution (CDR), the Organs of Popular Power (OPP), and the mass organisations (including: Municipal Delegates, Provincial/National Assemblies, Work Commissions, Popular Councils) is about enabling people to have a voice for direct democracy. The word democracy etymologically is a combination of demos meaning [common] people and kratos meaning power, thereby constructed as people-power this seems to be the case in Cuba. Similar principles to those applied in Cuba were also established as part of the then Chavez-led re-writing of the Venezuelan constitution, and subsequently where people were permitted to recall and remove their President before the end of their term. One must question the fate of Tony Blair and George Bush if this principle for democracy had been in place in the UK/USA on the issue of the invasion of Iraq, and on the issue of austerity in Spain and many parts of the capitalist 'democratic' world.

Being educated in the tools to do critical thinking is fundamental for feasibility of an alternative to generate, and it could be speculated that the ruling class are making higher education unaffordable in many countries and making access to a critical and creative curriculum unobtainable (for by example cutting funding for social science and humanities funding) because it opens the way for workers and the working class to be educated about neoliberalism, mystification, and feasibility.

The educative work for class struggle at the level of culture that, for example, Brand and other organic intellectuals practice represents a negation of the claims of the capitalist ruling class. This kind of negation of negation - a sidestepping of the mystification of the capitalist mode of production and creating a feasibility of an alternative to be possible represents a crisis moment in terms of what Thomas has described as placing the "very foundations of bourgeois hegemony in doubt" (2009, p.145). The role of education inside of and beyond formal State institutions is crucial here. This "doubt" must also be accompanied by effective strategizing that takes seriously questions of class as the basis of cultural forms. These classed cultural forms create the conditions for consent, the importance of agential action of organic intellectuals, and also the unpredictable but conceivable tendencies of history to materialize in certain ways. Struggle for demystification and for alternatives to be feasible must be part of education in all its forms, thus to raise consciousness, only then can a momentum as an organised labouring class be established against the status quo (Marx, 1847).

\section{References}

Barnes, T. (2017). Migrant's son swaps the East End for Eton after winning scholarship. The London Evening Standard. Thursday 
2 March 2017. Available from: http://www.standard.co.uk/ news/education/migrants-son-swaps-the-east-end-for-etonafter-winning-scholarship-a3479781.html

BBC (1999). 'UK Thatcher stands by Pinochet', BBC News, March 26 http://news.bbc.co.uk/1/hi/304516.stm

Brand, R. (2014). Revolution. London: Random House

Choonara, E. \& Robinson, S. (2008). Hunger in a World of Plenty. Socialist Workers Party.

Clark, T. G. (2012). 'What is Neoliberalism? http://anotherangryvoice.blogspot.co.uk/2012/09/what-is-neoliberalism-explained.html

Forbes (2011). The Four Companies That Control the 147 Companies That Own Everything.

Forgacs, D. (2000). The Gramsci Reader: Selected Writings 19161935. New York, New York: University Press.

GATS (1994). https://www.wto.org/english/docs_e/legal_e/26gats.pdf

Gramsci, A. (1971). Selections from the Prison Notebooks of Antonio Gramsci, London: Lawrence and Wishart.

Lawton, L. (2012). 'Liam's Labrynth' https://liamos85.wordpress. com/2012/07/12/a-critical-assessment-of-the-impact-of-neoliberalism-on-the-chilean-state-during-the-pinochet-regime-1973-1989/

Maisuria, A. (2017). Mystification of production and feasibility of alternatives Social class inequality and education. In Cole, M. (2017) Education, Equality and Human Rights [4 $4^{\text {th }}$ Ed]. London: Routledge

Maisuria, A. \& Cole, M. (2017). The Neoliberalisation of Higher Education in England: An Alternatives is Possible. Policy Futures in Education. Vol 15 (3) pp.602-619

Maisuria, A. (2014). The Neoliberalisation Policy Agenda and its Consequences in England: A Focus on Resistance Now and Possibilities for the Future. Policy Futures in Education. 12(2) pp 286-296
Marmol, E.; Hill, D.; Maisuria, A.; Nocella, A.; \& Parenti, M. (2015). The Corporate University: An E-interview. Critical Education. The Institute for Critical Education Studies. http:// ices.library.ubc.ca/index.php/criticaled/article/view/185102

Martinez, E. \& García, A. (2000). 'What is Neoliberalism? A Brief Definition for Activists' National Network for Immigrant and Refugee Rights http://www.corpwatch.org/article. php?id=376

Marx, K. (1867). Capital Volume One: [Online]. Marxist Internet Archive. Available: https://www.marxists.org/archive/marx/ works/1867-c1/ch13.htm

Marx, K. (1859). Preface of A Contribution to the Critique of Political Economy Online]. Marxist Internet. Archive. Available: https://www.marxists.org/archive/marx/works/1859/critique-pol-economy/preface-abs.htm

Marx, K. \& Engels, F. (1848). Manifesto of the Communist Party [Online]. Marxist Internet Archive. http://www.marxists. org/archive/marx/works/1848/communist-manifesto/index. htm

Marx, K. (1847). Poverty of Philosophy [Online]. Marxist Internet Archive. Available: https://www.marxists.org/archive/ marx/works/1847/poverty-philosophy/

Mayo, P. (2015). Hegemony and Education Under Neoliberalism: Insights from Gramsci. London: Routledge.

Rikowski, G. (2001). After the Manuscript Broke Off: Thoughts on Marx, Social Class and Education. British Sociological Association Education Study Group Meeting. King's College London.

Thomas, P. D. (2009). The Gramscian Moment: Philosophy, Hegemony and Marxism. Leiden; Boston: Brill.

Vitali S., Glattfelder J.B. \& Battiston S. (2011). The Network of Global Corporate Control. PLoS ONE 6 (10) 
